\title{
A COMPARATIVE STUDY OF PHRASEOLOGICAL UNITS VERBALIZING THE CONCEPT OF "LOVE" IN ENGLISH AND UZBEK
}

\section{Mirzayeva D.I.}

Teacher, Fergana State University, Uzbekistan

Ergasheva N.T.

Master, Fergana State University, Uzbekistan

\section{ABSTRACT}

This article is a comparative analysis of the phraseological units in English and Uzbek that verbalize the concept of "love", which explores the similarities and differences between the phraseological units in both languages, revealing the factors that require them.

KEYWORDS: - Anthropocentric paradigm, phraseology, nominative phraseological units, communicative phraseological units, lingvocultures.

\section{INTRODUCTION}

The modern stage of cognitive linguistics is characterized by anthropocentrism, which focuses on the inner world of man. Consequently, the feeling of love is undoubtedly of interest to linguists because it is an important part of one's inner world. As language serves people, it is not only a means of communication, but also reflects the cultural life, emotional experiences, mentality, history and way of life of people. Therefore, in this article, we want to explore the phraseological units of love cognitively in both languages.

First of all, the study of dictionaries in both languages revealed the following meanings and definitions of the concept of "love":

In the Uzbek language:Love-1. a deep intimate, sincere and selfless attitude of members of the opposite sex to each other; love

2. Feelings of love and affection for someone or something close to you. [Explanatory dictionary of the Uzbek language, 470]

In English:

Love-1. a profound and caring affection toward someone. 2. A deep or abiding liking for something; enthusiasm for something. [Oxford English Dictionary]

(1. Strong and caring love for someone. 2. Loving something deeply and for a long time, passion for something)

Love- 1.a very strong emotional and sexual feeling 
CURRENT RESEARCH JOURNAL OF PHILOLOGICAL SCIENCES 2(11):

117-123, November 2021

DOI: https://doi.org/10.37547/philological-crjps-02-11-26

ISSN 2767-3758

(C)2021 Master Journals

Crossref do

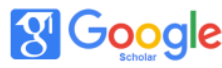

Accepted $25^{\text {th }}$ November, 2021 \& Published $30^{\text {th }}$ November, 2021

for someone .2.the feeling of liking and caring for someone such as a member of your family or a close friend. [Macmillan English Dictionary]

a strong mental and physical inclination towards a person. 2. A feeling of liking and caring for someone close to you, such as a family member or close friend)

From the above definitions we can see that the concept of love mainly refers to the love relationship between people of both sexes. Second, we can also use the concept of love to express love for the Homeland, art, labor, nature, God, parents, and friends. Humanity defines love as passion, dependence on knowledge, money, power, respect for others.

This article examines the phraseological units of love, first of all, it is necessary to describe the phraseological units. "A phrase is the second linguistic unit belonging to the lexical stage of language construction and consists of a semanticsyntactic combination of more than one lexeme, hence the composite segment unit; syntactically it is equivalent to a compound, a verb, and usually has a nominative and a signifiable function, but differs from a lexeme not only in its expression but also in its content.

In the literature, this linguistic unit is referred to by terms such as phraseology, phraseological unit; the lexeme prefers to be called a phrasal verb in accordance with the terms morpheme. The field of study of phrases is called phrasing (the term phraseology is used in the literature). Thus, we can see from this definition that a phrase is two or more words that are not formed by free choice of words in speech, are equivalent to a phrase and a sentence, and are used in a figurative sense as a whole.

Leading linguist in Uzbek linguistics - phraseologist Sh. Rakhmatullaev classifies phraseological units in terms of semantic types into a) nominative (nominative) phraseological units, b) expressive (communicative) phraseological units. Based on this classification, there is every reason to divide the phraseology that promotes the concept of "love" into the following types:

Nominative phraseological units: ko`ngli qattiq, ko`ngli tosh, yuragi tosh, bag`ri tosh, ko`z qorachig`i, ko`zining oq-u qorasi ,ko`ngil bo`lmoq, ko`ngil bog'lamoq, ko`ngil qo`ymoq, ko`ngil bermoq, yaxshi ko`rmoq, ko’nglini ochmoq , yuragini ochmoq, ko'ngli bor, ko'ngil ovlamoq, ko'ngil topmoq, ko'nglini olmoq ,ko`nglini topmoq, ko`ngli sovidi, ko`ngli qoldi, aql-u hushini yo`qotmoq, boshini/bosh-u ko`zini aylantirmoq, dili tortdi, ko`ngli tortdi, jini suymaslik/jiniga yoqmaslik, jigaridan/yuragidan urmoq, ishqi tushdi/mehri tushdi, ko`ziga issiq ko`rinmoq, yaxshi ko'rmoq, yomon ko'rmoq, ishqi tushmoq, yurak-bag'ri qon bo'ldi, yuragidan sidirib tashlamoq, yuragiga qo'l solmoq/ko'ngliga qo'l solmoq,yulduzi yulduziga to'g'ri keldi, es-hushini olib qo'ymoq eng: apple of my eye , be an item, blind date, double dating, drive someone crazy, get hitched, have the hots for, head over heels ,leave at the altar, love is blind, love rat, lovey-dovey, no love lost, on cloud nine, on the mend, on the rocks near the end, puppy love, love through thick and thin, tie the knot, to fancy someone, walk out on someone, whisper sweet nothings, a love nest, to have eyes only for someone , cupboard love, loveseat etc.

Communicative phraseological units: uzb: Birov parini sevibdi, Birov - qurbaqani; Vafoli qul jafoli qul; Gul — bahona, diydor — g'animat; Gul hayot bezagi, Sevgi - inson bezagi; Gulga boq, tikanni ko'r, Yorga boq, jafoni ko'r; Gulsiz bulbul yorsiz bulbul; Davosiz dard - muhabbat; Yolg'izlikda yor yaxshi; Yorim bor deb yorilma, Haqiqiy yor bo'lmasa; Yoshlikda bergan ko'ngil, Ayrilmas balo bo'lur; Ikki pichoq bir qinga sig'mas, Ikki sevgi - bir ko'ngilga; Ikki suyuk bir ko'ngilga sig'mas; Inson bo'lsang vafo qil, Vafosizlik - xato, bil; Inson sevgi bilan tirik; Intizorlik o'limdan yomon; Ishq bilan o'ynashib bo'lmas; Ishq boshqa, havas boshqa; Ishq - muqaddas o't, Havas - loyqa suv; Ishqi bor o'ynar, Dardi bor yig'lar; Ishqi borning imoni bor; Ishqsiz ko'ngil - egasiz uy; Ishqsiz ko'ngil - o'tsiz o'choq; Kuygan o'lanchi 
CURRENT RESEARCH JOURNAL OF PHILOLOGICAL SCIENCES 2(11):

117-123, November 2021

DOI: https://doi.org/10.37547/philological-crjps-02-11-26

ISSN 2767-3758

(C2021 Master Journals

\section{Crossref do) 8 : Google}

Accepted $25^{\text {th }}$ November, 2021 \& Published $30^{\text {th }}$ November, 2021

bo'lar, Suygan - laparchi; Ko'z qarisa ham, ko'ngil qarimas; Ko'ngil ko'ngildan suv ichar; Ma'shuq qayda bo'lsa, Oshiq shunda bo'lar; Muhabbat - bir so'z, ma'nosi - dunyo; Muhabbat boylikka boqmas; Muhabbat - dil mevasi; Muhabbat yosh tanlamas vkz. Ing: The way to a man's heart is through his stomach; There is no difference between a wise man and a fool when they fall in love; Absence makes the heart grow fonder; Two shorten the road; Opposites attract.; Beauty is in the eye of the beholder; The heart wants what it wants; Love is blind; Love conquers all; Love will find a way; Love makes the world ground; Love knows no bounds; Blood is thicker than water; Home is where the heart is; You can choose your friends, but you can't choose your family; That's a face only a mother could love; Tough love; Happy wife, happy life; You can't love until you love yourself; Love yourself or

\begin{tabular}{|c|c|}
\hline $\begin{array}{l}\text { Ko`ngli qattiq/ko`ngli tosh/ /yuragi tosh/bag ri } \\
\text { tosh- mehr-shafqati yo`q. "Umrida faqat bir yoki } \\
\text { ikki marta ko`ziga yosh olgan ko`ngli qattiq, } \\
\text { baquvvat erkaklargina shunday yig`laydi”. [Asqad } \\
\text { Muxtor,Tug`ilish] }\end{array}$ & $\begin{array}{l}\text { Having a heart of stone- a cold and unfeeling } \\
\text { nature. } \\
\text { 'His heart is as firm as a stone; as hard as a } \\
\text { piece of the nether millstone '.[Bible] }\end{array}$ \\
\hline $\begin{array}{l}\text { Ko`ngli sovidi/ko`ngli qoldi- kimnidir sevmay } \\
\text { qo`yish. } \\
\text { “Rost bekitishning nima keragi bor, Qo`chqordan } \\
\text { ko`ngli sovib yurganida, Sherbek ko`ziga o`tdek } \\
\text { issiq ko 'rinib ketdi.”[S.Anorboyev,Oqsoy] }\end{array}$ & $\begin{array}{l}\text { Can't stand the sight of someone- not liking } \\
\text { someone any more } \\
\text { 'She can't stand the sight of him`. }\end{array}$ \\
\hline $\begin{array}{l}\text { Ko'ngil ovlamoq - o'ziga moyil qilish uchun } \\
\text { intilmoq. O'xshashi: ko'ngliga yo 'l topmoq. }\end{array}$ & $\begin{array}{l}\text { To whisper sweet nothings- to speak to } \\
\text { someone very flirtatiously. }\end{array}$ \\
\hline $\begin{array}{l}\text { Ko'nglini ochmoq }- \text { biror odamga ichki } \\
\text { hissiyotlarini aytish }\end{array}$ & $\begin{array}{l}\text { To wear your heart on your sleeve- openly } \\
\text { show your emotions with no qualms. }\end{array}$ \\
\hline $\begin{array}{l}\text { Ko`z qorachig`i/ Ko`zining oq-u qorasi- yakka- } \\
\text { yu yagona va qadr-qimmati-beqiyos yuksak. }\end{array}$ & $\begin{array}{l}\text { To be the apple of someone`s eye- to be loved } \\
\text { by someone }\end{array}$ \\
\hline
\end{tabular}

no one else will; Wanting to be someone else is a waste of the person you are; Lend yourself to others, but give yourself to yourself; Short, sweet and to the point; All is fair in love and war; Love hurts; If you love someone, let them go. If they come back to you, they were really yours; Hell hath no fury like a woman scorned; Time heals all wounds; Love me, love my dog etc.

The following table identifies and places all the phraseological units related to love in Shavkat Rakhmatullayev's "Explanatory phraseological dictionary of the Uzbek language" and finds as many equivalent phrases in English as possible and gives similar expressions in both languages with examples and descriptions.

\section{https://masterjournals.com/index.php/crjps}


CURRENT RESEARCH JOURNAL OF PHILOLOGICAL SCIENCES 2(11):

117-123, November 2021

DOI: https://doi.org/10.37547/philological-crjps-02-11-26

ISSN 2767-3758

(C)2021 Master Journals

crossref do) 801 Google

Accepted25 $5^{\text {th }}$ November, 2021 \& Published 30th November, 2021

\begin{tabular}{|c|c|}
\hline $\begin{array}{l}\text { "Ko zimning qorachig'I qishloqda qoldi. } \\
\text { [I.Rahim,Chin muhabbat] }\end{array}$ & $S h$ \\
\hline $\begin{array}{l}\text { Ko`z suzmoq- e`tiborini qaratish uchun noz- } \\
\text { karashma qilmoq. } \\
\text { “. .. Nuqul atlas-u girindishin kiyib, tovusday } \\
\text { yaltiragan qizlar bilan bog`to lib ketadi. Bilaman, } \\
\text { bari o`g limga ko`z suzadi”.[Oybek, Oltin vodiydan } \\
\text { shabadalar] }\end{array}$ & $\begin{array}{l}\text { Make eyes at- to look at someone with sexual } \\
\text { interest. } \\
\text { 'She was making eyes at him all evening`. }\end{array}$ \\
\hline 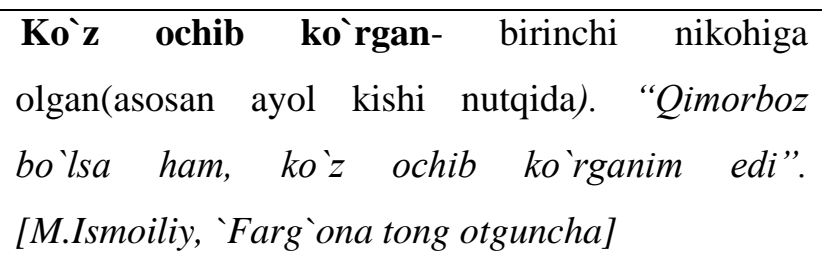 & $\begin{array}{l}\text { Be the first love- the person you love first in a } \\
\text { romantic way. } \\
\text { 'Why did he hide the fact that his first love would } \\
\text { be here tonight?' }\end{array}$ \\
\hline $\begin{array}{l}\text { Ko`zini qamashtirmoq- go`zalligiga mahliyo } \\
\text { bo`lmoq. }\end{array}$ & $\begin{array}{l}\text { To catch someone's eye- to be attractive to } \\
\text { someone. } \\
\text { 'The shy girl at the back of the class caught my } \\
\text { eye'. }\end{array}$ \\
\hline $\begin{array}{l}\text { Ko`zini ko`r, qulog`ini kar qilmoq- } \\
\text { hech narsani ko`rmaydigan, eshitmaydigan qilmoq. } \\
\text { “Biroq qizi tushkurning husnimi, shirin so `zlarimi, } \\
\text { har qalay, G`iyosiddinning til-jag `ini bog `lab, } \\
\text { qulog `ini kar,ko`zini ko`r qilib qo ygan edi”.[ Said } \\
\text { Ahmad, Hukm] }\end{array}$ & $\begin{array}{l}\text { Blinded by love } \\
\text { when a person is so madly in love with } \\
\text { somebody that they can't see the persons faults } \\
\text { or negative characteristics } \\
\text { 'She is so blinded by love that she can't see him } \\
\text { for who he truly is. He is not a good person, he is } \\
\text { rude and disrespectful to everyone around him: }\end{array}$ \\
\hline $\begin{array}{l}\text { Ko`zi-ko`ziga tushdi- ko`z qarashlari bir daqiqa } \\
\text { duch keldi. O`xshash: ko`z urishtirmoq. “Omon } \\
\text { ham uni zimdan kuzatar,ko`zi-ko`ziga tushganda } \\
\text { birdan tund bo `lib qolardi.”[Said Ahmad. } \\
\text { Muhabbatning tug`ilishi] }\end{array}$ & $\begin{array}{l}\text { To meet one`s eyes- to make eye-contact with } \\
\text { someone. } \\
\text { 'Ifelt too shy to meet her eye`. }\end{array}$ \\
\hline Ko`ziga & \\
\hline
\end{tabular}


CURRENT RESEARCH JOURNAL OF PHILOLOGICAL SCIENCES 2(11):

117-123, November 2021

DOI: https://doi.org/10.37547/philological-crjps-02-11-26

ISSN 2767-3758

(C)2021 Master Journals

\section{Crosser do) 78l Google}

Accepted25th November, 2021 \& Published 30 ${ }^{\text {th }}$ November, 2021

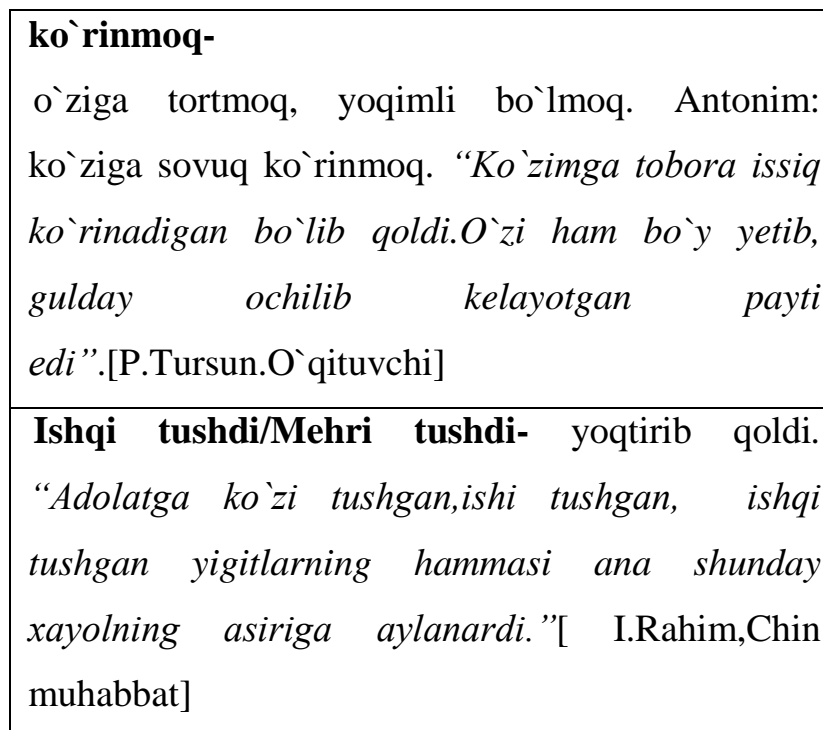

Jigaridan/yuragidan urmoq- o’ziga shaydo qilib olmoq. “Q Qo yingki do`ndiqcha jigardan urib qoldi. Nima qilsam yoqarkanman deb o`lib bo 'laman”. [S.Anorboyev. Oqsoy]

Jini suymaslik/jiniga yoqmaslik- yomon
ko`rmoq. "Birovning ishiga aralashgan kishini jinim suymaydi. ’[Said Ahmad. Qadrdon dalalar] very attractive.

She has got the hots for the new office manager.

One`s heart skips/ misses a beat- feel so excited that heart beats faster.

'Her heart skipped a beat as a lean figure in a business suit entered the room.

\section{Be sick of the sight of someone or something-} dislike when encountering

'At this point, he is betrayed me so many times that I $\mathrm{m}$ sick of the sight of him

Aql-u hushini yo`qotmoq- o`z harakatlarini ongli To be madly in love -

ravishda boshqara olmaydigan darajaga yetmoq. "Qizlar yaxshi ko’rib qolganda aqlini yo qotib qo`yishadi deyishadi. Zamira aqlini yo`qotib qo 'yganda hayoli shunday ravshan bo 'larmidi?’"[ P.Qodirov. Uch ildiz]

Yulduzi yulduziga to'g'ri keldi. Varianti: yulduzlari to'g'ri keldi.

“ Bu nikohga o'zing rozi bo'lding,endi uni shubhaga solma.Yulduzi yulduziga to'g'ri kelsa, to be deeply or extremely in love with somebody

'They are madly in love, they love and trust each other and will always be loyal to one another.

\section{Match made in heaven}

a relationship in which the two people are great together, because they complement each other so well 
CURRENT RESEARCH JOURNAL OF PHILOLOGICAL SCIENCES 2(11):

117-123, November 2021

DOI: https://doi.org/10.37547/philological-crjps-02-11-26

ISSN 2767-3758

(C)2021 Master Journals

crossref do) 8: Google

Accepted25 $5^{\text {th }}$ November, 2021 \& Published 30th November, 2021

\begin{tabular}{|c|c|}
\hline Rahim.Ihlos] & $\begin{array}{l}\text {-Do you think Matt and Amanda will get } \\
\text { married? } \\
\text {-I hope they will. They're a match made in } \\
\text { heaven: }\end{array}$ \\
\hline $\begin{array}{l}\text { Es-hushini olib qo'ymoq- o'ziga o'ta darajada } \\
\text { mahliyo qilib olmoq. O'xshashi: xushi ketdi, esi } \\
\text { og'di. "G'ulomjon:"To'g'ri aytasiz,esimni olib } \\
\text { qo'yishgan",-demoqchi bo'ldi-yu, negadir } \\
\text { demadi”.[M.Ismoiliy.Farg'ona tong otguncha] }\end{array}$ & $\begin{array}{l}\text { Be head over heels (in love) } \\
\text { be in love with somebody very much } \\
\text { 'Look at them. They're head over heels in love } \\
\text { with each other. }\end{array}$ \\
\hline $\begin{array}{l}\text { Daraxtni silkitsang, qiz yog iladi- bundan boshqa } \\
\text { qizlar serob ma`nosini beradi va biror qiz } \\
\text { tomonidan rad qilinganda ishlatiladi. } \\
\text { "Daraxtni silkitsang ,qiz yog`iladi deb qayta } \\
\text { sovchilik ishini boshlagan opalarim hamma } \\
\text { eshikdan quruq qaytishdi”. [ Seni tashlab ketganim } \\
\text { yolg`on,o`g`lim. Hikoya.Darakchi] }\end{array}$ & $\begin{array}{l}\text { There are plenty more fish in the sea. } \\
\text { People commonly say this to someone after a } \\
\text { breakup to remind them that there are many other } \\
\text { eligible people available. } \\
\text { 'There are plenty of other fish in the sea, I told } \\
\text { my friend when she separated from her } \\
\text { boyfriend. }\end{array}$ \\
\hline
\end{tabular}

A comparative analysis of the examples in English and Uzbek, which typologically belong to different language families, leads us to the following conclusions:

1) Nominative and communicative phraseological units expressing the concept of "love" in both languages should be called lingvocultures, as these units are important in the languages and cultures of the English and Uzbek peoples and are specialized verbs to realize their unique ethnolinguistic and linguoculturological features. means it is no exaggeration to say;

2) Phraseologisms in the compared languages differ from each other as unique national units lingvocultures. In this respect, although their formal features, i.e. their superficial structures, are radically different, they differ somewhat in some semantic components as well as in their semantic similarity. For example, certain nominative phraseological units in Uzbek, as well as communicative phraseological units and some communicative phraseological units in English, indicate that the language and culture of a people have its own linguoculturological features. Such phraseological units should be given serious consideration in the process of reading and translation, otherwise the ethnolinguistic and linguocultural features of languages may not be revealed in the process of their study and application.

3) While the similarities of the phraseological verbalizers of the concept of love in the compared languages are explained by the 
CURRENT RESEARCH JOURNAL OF PHILOLOGICAL SCIENCES 2(11):

117-123, November 2021

DOI: https://doi.org/10.37547/philological-crjps-02-11-26

ISSN 2767-3758

(C)2021 Master Journals

crossref do) 8: Google

Accepted25 $5^{\text {th }}$ November, 2021 \& Published 30th November, 2021

application of the general laws of development in languages, their differences are due to the specificity of the thinking of writers in this or that language, explained.

\section{REFERENCES}

1. Kunin A.V. Kurs frazeologii sovremennogo angliykogo yazыka. - Moskva: Vыsshaya shkola, 1986. - 336 s. 1. Bondarko A.V. Funksionalno-semanticheskie polya.- L.: Nauka, 1983 ;

2. Michael McCarthy Felicity O`Dell. English Idioms in Use. Cambridge University Press. 51$52-b$

3. Kubryakova Ye. S. O kognitivnoy lingvistike i semantike termina "kognitivnuy" // Vestnik Voronejskogo gosudarstvennogo universiteta Seriya: Lingvistika i mejkulturnaya kommunikatsiya. - Voronej, 2001.

4. Raxmatullaev Sh. O'zbek tilining izohli frazeologik lug'ati, T., "O'kituvchi”, 1978.

5. Hoshimov G'. M., Ziyaev A. "Intensifikatsiya deintifikatsiya" konseptual semantikasi verbalizatorlarining kognitiv tipologiyasi // FarDU. Ilmiy xabarlar, 4 - 2017, 75-81b.

6. Ashurova D.U., Galieva M.R. Cognitive Linguistics, VneshInvestProm, 2018 - 159.

7. Rasuljanovna, I. N. (2020). The verbal lacunas in chinese and uzbeklanguages (on the example of grammatical and somatic lacunas). ACADEMICIA: An International Multidisciplinary Research Journal, 10(5), 1961700.

8. Rahmatullayev Sh. Hozirgi o`zbek adabiy tili.Toshkent."Universitet" 2006. 420-b 